\title{
Drosophila melanogaster as a model for nutrient regulation of ovarian function
}

\author{
Alissa Richmond Armstrong ${ }^{1}$ \\ ${ }^{1}$ Department of Biological Sciences, University of South Carolina, Columbia, South Carolina, USA \\ Correspondence should be addressed to A R Armstrong; Email: armstrar@mailbox.sc.edu
}

\begin{abstract}
Observed in a wide variety of organism, from invertebrates to mammals, nutritional status modulates the energetically costly effort of producing female gametes. Despite this long-standing link between nutrition and ovarian function, relatively little is known about the cellular and molecular mechanisms that underlie how dietary components modulate egg production. Drosophila melanogaster, with its powerful and extensive genetic tools as well as its well-characterized ovarian response to diet, has proven to be instrumental in addressing this issue. This review covers what we currently know about the dietary control of oogenesis in Drosophila and the salient features of the fruit fly that make it a model for nutritional control of ovarian function.

Reproduction (2020) 159 R69-R82
\end{abstract}

\section{Dynamic organismal macronutrient intake influences ovarian function}

Many organisms experience variations in macronutrient intake across small (e.g. meal to meal, day to day, week to week) and large (e.g. infancy, childhood, early adulthood, late adulthood) timescales. These changes can be involuntary, as in the extreme case of famine, or voluntary, as in the case of individuals choosing to go on the low-carbohydrate, high-protein Atkins diet. Variations in macronutrient intake generally result from alterations in all five macronutrients, carbohydrates, proteins, fats, fiber and water, or one macronutrient. For example, under a caloric restriction dietary regimen, there is a $20-40 \%$ decrease in total calorie intake without reaching malnutrition (Lee \& Longo 2016). Conversely, in cases of over-nutrition, too many nutrients are consumed and too little activity is undertaken, leading to an imbalance between caloric intake and energy expenditure. Dozens of fad diets are often employed for weight loss and/or disease amelioration. For example, a diet low in carbohydrates relative to fats and protein is thought to improve glucose tolerance in patients with type 2 diabetes (Meng et al. 2017). Given the inextricable link between nutritional input and whole organismal physiology, alterations in dietary intake can positively or negatively affect metabolism, inflammation, temperature regulation, blood pressure and reproduction (Heymsfield \& Wadden 2017).

Nutritional status influences reproduction at the level of gametogenesis, particularly ovarian function, in a wide range of organisms, from invertebrates, like worms and insects, to large domestic animals, like sheep and pigs
(Wheeler 1996, Drummond-Barbosa \& Spradling 2001, Terashima \& Bownes 2004, Lopez et al. 2013, Sohrabi et al. 2015, Hohos \& Skaznik-Wikiel 2017, Wang et al. 2017). For example, high-fat diet leads to poor ovarian function as evidenced by more ovarian follicle death and fewer maturing follicles in rabbits (Cordier et al. 2013) or an increase in immature, at the expense of developing, follicles in mice (Solon-Biet et al. 2015). Conversely, ovaries from mice fed a calorically restricted diet contained a larger pool of developing follicles and fewer atretic follicles, compared to female mice fed ad libitum, ultimately leading to improved fertility and fecundity (Selesniemi et al. 2008). The vast majority of research addressing nutritional control of ovarian function in mammalian systems, including humans, has been tied to the framework of obesity (Hohos \& SkaznikWikiel 2017, McGrice \& Porter 2017) and obesityrelated reproductive diseases, like polycystic ovarian syndrome (Jarrett \& Lujan 2016). This is understandable given that over $50 \%$ of reproductive age women are considered to be overweight or obese (Delcore \& Lacoursiere 2016) and that most Americans incorporate too few vegetables, fruit and dairy and too much added sugar, saturated fats and sodium, according to the 20152020 Dietary Guidelines for Americans. Before we can understand what goes awry under circumstances of aberrant nutrition, it will be important to elucidate the cellular and molecular mechanisms that underlie the ovarian response to an organism's nutritional intake.

Over the last decade, Drosophila melanogaster, the fruit fly, has emerged as an important player in metabolism and physiology studies (Baker \& Thummel 2007, Rajan \& Perrimon 2013, Trinh \& Boulianne 2013) 
with many focused on the effects of maternal nutrition on reproduction and offspring health (Brookheart \& Duncan 2016). The goal of this review is to highlight the utility of Drosophila as an in vivo model organism to understand the dietary influences on ovarian function. Morphological similarities between fruit fly and human ovaries as well as stages of Drosophila oocyte development are described. Readers will find information on the overall influence of diet on ovarian output (i.e. oocyte production) in fruit flies, including the stages of oogenesis particularly sensitive to nutritional input. In addition, the molecular mechanisms known to function within the ovary and other tissues that mediate the effects of diet on ovarian function are discussed. Lastly, established reagents and tools used by Drosophila biologists to address this topic are described, including a sampling of Drosophila diet recipes, immunocytochemical reagents to visualize oogenesis, and transgenic tools to manipulate ovarian gene expression.

\section{Drosophila melanogaster as a model of nutritional physiology}

Several features of Drosophila melanogaster make it an ideal model organism to investigate fundamental principles in a variety of biological fields. First, large numbers of flies are easily maintained in a modest amount of space. Adults, which reach $3 \mathrm{~mm}$ in size, are housed in vials (for smaller numbers of flies) or bottles (for larger numbers of flies) containing a simple food source of cornmeal, yeast, sugar, water and agar. The 10-day egg-to-adult life cycle, in conjunction with reproductive robustness, allows for the rapid generation of a large number of progeny. Second, Drosophila boasts a genomic simplicity while being genetically and biologically complex. The diploid fruit fly has four chromosomes that hold approximately 14,000 proteincoding genes in $143.7 \mathrm{Mbps}$ of DNA compared to the 23 chromosomes that hold approximately 20,000 proteincoding genes in $3 \mathrm{Gbs}$ of human DNA. In addition to making genetic manipulations more straightforward, less genetic redundancy in flies often produces more robust mutant phenotypes due to lack of compensation by related genes. Despite dramatic differences in size, presence of a backbone, appendage morphology, and mode of temperature regulation, Drosophila and humans share between 40 and $60 \%$ of genes, with up to $75 \%$ of human disease-related genes having homologs in flies (Reiter et al. 2001). This makes Drosophila a wellsuited model for the study of human diseases (Millburn et al. 2016, Yamaguchi \& Yoshida 2018). Moreover, Drosophila employs a majority of the organ systems used by humans to regulate physiology including the nervous, musculoskeletal, respiratory, circulatory, digestive, excretory and reproductive systems (droso4schools. wordpress.com). Since its early use in elucidating the mechanisms of genetic inheritance, Drosophila melanogaster continues to hold a strong position as one of the premier model organisms used to investigate biological principles in a variety of fields, including cellular biology, development, physiology, behavior/ nervous system function, and gene expression.

Drosophila melanogaster is an excellent model organism to tease apart the intricate relationship between nutritional input and ovarian function. First, individual adult females have the capacity to lay up to 100 eggs per day for several days under optimal conditions (Drummond-Barbosa \& Spradling 2001). Secondly, the Drosophila ovary responds dramatically to a variety of dietary changes including starvation, dietary restriction, removal of specific macronutrients, and alterations in macronutrient ratios (Sang \& King 1961, Chippindale et al. 1993, Bradley \& Simmons 1997, Drummond-Barbosa \& Spradling 2001, Good \& Tatar 2001, Mair et al. 2004, Terashima \& Bownes 2004, Skorupa et al. 2008, Lushchak et al. 2012, 2014). Lastly, extensive research over several years has uncovered the involvement of multiple nutrient-sensing pathways in the ovary's ability to directly and indirectly sense and respond to nutritional status (Ables et al. 2012). Moreover, Drosophila melanogaster is a classic and powerful genetic system for which a wealth of reagents and transgenic organisms exist that allows spatial and temporal control of gene expression.

\section{The stem cell-supported ovary powers oocyte production in Drosophila melanogaster}

In the Drosophila ovary, multiple cell types work together to execute 14 developmental stages responsible for the continual production of mature oocytes over a female fly's reproductive lifespan (Spradling 1993, McLaughlin \& Bratu 2015). Like mammals, abdomens of Drosophila females house a pair of ovaries, each composed of approximately 18 individual units or ovarioles (Fig. 1A and B). The anterior-most tip of an ovariole, called the germarium, contains two stem cell populations: two-three germline stem cells (GSCs) at the anterior and two follicle stem cells (FSCs) just beyond the midpoint of the anterior-posterior axis. Three somatic cell types, including terminal filament, cap and escort cells, make up the stem cell niche that maintains GSCs in an undifferentiated state (Spradling et al. 2011). GSCs, which are physically attached to cap cells by cadherins, divide asymmetrically to selfrenew (the daughter that remains adhered to cap cells) and generate a cystoblast (the daughter cell that is one cell diameter removed from cap cells). Cystoblasts undergo four synchronous divisions with incomplete cytokinesis, creating two, four, eight and ultimately 16 interconnected germ cells, or germline cysts. In a 16-cell germline cyst, one cell becomes the oocyte proper and the remaining 15 become nurse cells. Before exiting the germarium, individual 

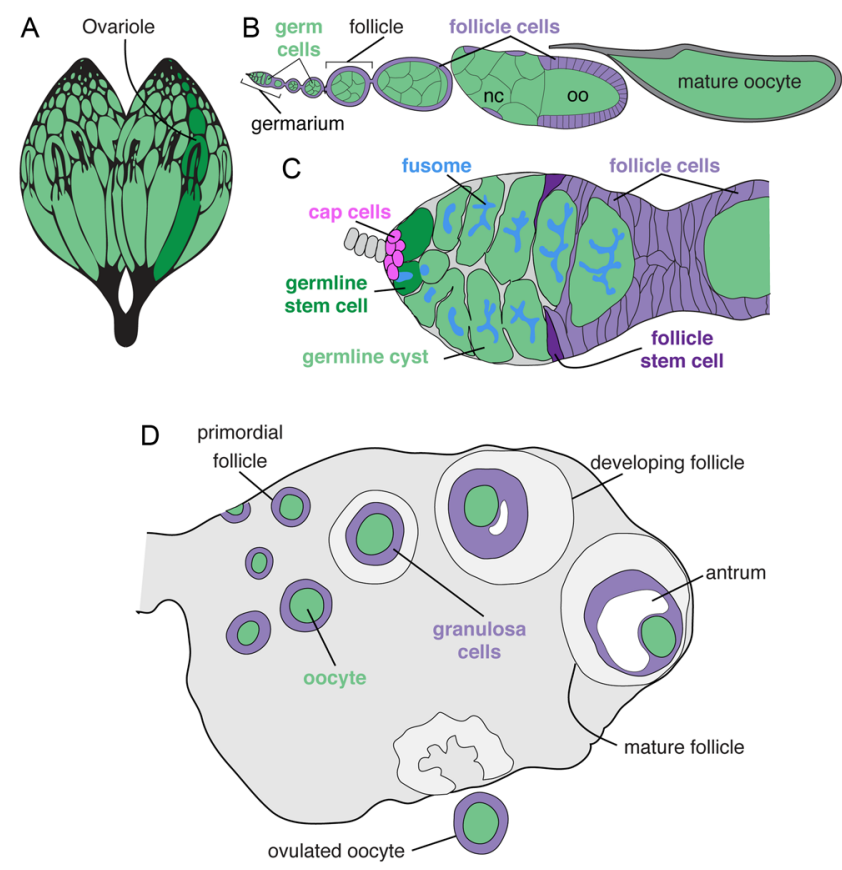

Figure 1 The Drosophila melanogaster ovary compared to the mammalian ovary. (A) The paired Drosophila ovary is composed of several individual ovarioles. (B) A single ovariole contains progressively older follicles composed of germ cells (green) surrounded by a layer of somatic follicle cells (purple). Each follicle contains 16 germ cells, 1 oocyte (oo) and 15 nurse cells (nc). (C) The germarium (g) houses germline stem cells (GSCs, dark green) and their progeny, germline cysts (light green). Cap cells (pink) are a major cellular component of the stem cell niche. Follicle stem cells (FSCs, dark purple) support continued generation of follicle cells (light purple). (D) Similar to fruit flies, the mammalian ovary contains several follicles at various stages of development or maturation (primordial, developing, and mature follicles). Each follicle contains the germ cell or oocyte (green) and a layer(s) of somatic cells (purple).

16-cell cysts acquire a single cell layer of epithelial follicle cells, which originate from FSCs, producing a discrete egg chamber. Each egg chamber undergoes 14 morphologically distinct developmental stages that include endoreplication of nurse cell nuclei, follicle cell proliferation and migration, yolk and lipid uptake by the growing oocyte, deposition of maternal effect products into the oocyte, nurse cell break down and eggshell formation (Spradling 1993, McLaughlin \& Bratu 2015). The mature oocyte then traverses the lateral and common oviduct to rest in the uterus where it is fertilized by sperm from a specialized sperm storage organ, the spermatheca, and oviposited on a suitable substrate (Spradling 1993). Under optimal laboratory conditions, a single wild-type adult female can lay approximately 80-100 eggs per day for several days (Drummond-Barbosa and Spradling), with a lifetime fecundity potential of up to 1000 progeny. While many environmental factors affect Drosophila egg production, nutrition is one of the most influential.

\section{Drosophila and mammalian ovaries share several characteristics}

Despite some obvious differences (e.g. ovarian relative to body size), Drosophila and mammalian ovaries have similarities regarding cellular organization and oocyte development (Fig. 1B and D). In both organisms, the ovary produces multiple, self-contained female gametes consisting of a single oocyte and a layer of support cells. In the fruit fly egg chamber, a single layer of epithelial follicle cells encloses nurse cells and the oocyte, while multiple layers of granulosa cells enclose the human ovum. Moreover, each individual reproductive unit in humans and fruit flies undergo a progressive series of coordinated steps to form a mature oocyte. The 14 stages of oocyte development traversed by egg chambers in the Drosophila ovariole are akin to human oocytes transitioning from primordial, primary, secondary, early and late antral follicles to germinal vesicle followed by meiotic maturation stages (El-Hayek \& Clarke 2016). A major part of this linear development includes support cell proliferation and oocyte growth mediated by support cell-oocyte communication.

In humans, granulosa cell number increases creating multiple layers from a single cell layer (Gougeon 2010), while Drosophila follicle cells undergo several rounds of division to produce 650-1000 from approximately 80 cells (Horne-Badovinac \& Bilder 2005). Concomitantly, the human oocyte grows in size from 40 to $140 \mu \mathrm{m}$ (Gougeon 2010), while Drosophila oocytes grow from 10 to approximately $500 \mu \mathrm{m}$ (Spradling 1993). Transport of cellular constituents from support cells to the oocyte mediates this extensive increase in size, thus preparing oocytes for early embryonic development following fertilization. In Drosophila, the 15 nurse cells and oocyte are all interconnected by actin and microtubule rich intercellular bridges or ring canals (Lu et al. 2017). Given that the Drosophila oocyte is transcriptionally silent, nurse cells provide the oocyte with mRNAs, organelles, and proteins important for oocyte specification, embryonic patterning, and energy reserve (Mahowald \& Strassheim 1970, Spradling 1993, Clark et al. 2007, Nicolas et al. 2009, Lu et al. 2017). For example, mitochondria redistribute in a stage-specific manner from nurse cells to the oocyte through ring canals (Cox \& Spradling 2003). In fetal mouse ovaries, transport of cellular material through transient, interconnected germ cell cysts is thought to play a role in oocyte determination (Lei \& Spradling 2016, Ikami et al. 2017). Similar to Drosophila ring canals, proper mammalian follicular maturation relies on transzonal projections, actin- and connexin-rich cytoplasmic extensions that connect granulosa cells to the underlying oocyte (El-Hayek \& Clarke 2016). Transzonal projections allow granulosa cells to provide growth factors, metabolites, and amino acids to the growing oocyte (El-Hayek \& Clarke 2016). While it is not thought that transzonal projections 
mediate the transport of organelles, mammalian ovaries do experience modifications of cellular components. For example, mitochondria in human oocytes move from the cellular periphery to the central zone (Sundström et al. 1985). Lipid droplets also redistribute during oocyte maturation and growth in mammals in addition to an increase in size and number (Gu et al. 2015). In Drosophila, lipid accumulation is a hallmark of the process of vitellogenesis during oocyte development (Buszczak et al. 2002, Parra-Peralbo \& Culi 2011).

Arguably, the major difference between human and Drosophila ovaries is the existence of a stem cell population. Drosophila ovarian germline stem cells have been extensively characterized (Spradling et al. 2011), while the presence of stem cells in the mammalian/ human ovary remains controversial (De Felici \& Barrios 2013, Grieve et al. 2015, Hummitzsch et al. 2015). Nonetheless, conserved biological phenomena, like cellular proliferation, survival and intercellular signaling, must properly occur in ovaries of both organisms to generate functional female gametes.

\section{Dietary macronutrient composition determines ovarian function in Drosophila melanogaster}

Various types of standard fruit fly laboratory diets contain ingredients that provide carbohydrates, protein, and fats. An extensive body of Drosophila melanogaster literature exists examining how dietary macronutrients influence egg production, the ultimate output of ovarian function. Female flies fed a carbohydrate-only diet, in the form of sucrose or molasses, display a severe reduction in egglaying rates (Bownes \& Blair 1986, Drummond-Barbosa \& Spradling 2001) and lifetime fecundity (Good \& Tatar 2001). For example, a standard diet supplemented with yeast paste results in an average of 100 eggs in $24 \mathrm{~h}$ per female, while a diet of only $10 \%$ sucrose results in 10 eggs per female in the same amount of time (DrummondBarbosa \& Spradling 2001). Varying the total amount of food available, by diluting standard fly food media, shows that egg-laying rate correlates positively with increasing total food level (Chapman \& Partridge 1996, Bross et al. 2005). The vast majority of studies, however, manipulate the protein-to-carbohydrate ratio (P:C) by changing the amount of sucrose or yeast added to standard food media.

Despite differences in feeding paradigms (i.e. exact P:C ratios, yeast vs a defined protein source, solid vs liquid diets, and length of feeding), there is an overall consensus that dietary protein supersedes carbohydrates in promoting egg production. For example, increasing protein concentration by adding yeast to diets containing a constant carbohydrate concentration, leads to increased egg laying (Bradley \& Simmons 1997, Zajitschek et al. 2013). More recently, nutritional geometry has been employed to analyze the independent and interactive effects of protein and carbohydrates on life-history traits influenced by nutrition, like reproduction (Archer et al. 2009, Simpson et al. 2015, Jang \& Lee 2018). In studies testing over 20 different diets, it was revealed that the maximal rate of egg production is achieved when female flies consume a diet high in protein but with moderate-to-low levels of carbohydrates (Lee et al. 2008, Skorupa et al. 2008, Lushchak et al. 2012, Jensen et al. 2015). Moreover, the dietary condition of low overall food amount, that is low protein and low carbohydrate, built into these nutritional geometry studies show the expected detrimental effect on egg production (Chapman \& Partridge 1996, Lee et al. 2008, Skorupa et al. 2008). Interestingly, diets high in carbohydrates negate the positive effects of protein. Female fruit flies fed diets containing high-protein and high-carbohydrate levels have smaller ovaries with less active oogenesis (Brookheart et al. 2017) and lay very few eggs (Skorupa et al. 2008). Likely because of the small amount of lipids supplied in the diet relative to proteins and carbohydrates, the role that dietary fats play in modulating Drosophila egg production has received little, if any attention. Thus, in Drosophila melanogaster, dietary protein acts as the most prominent influencer of ovarian function with some modulation by dietary carbohydrates.

While most studies focus on how dietary changes in protein and/or carbohydrates in general modulate egg production, each class of macronutrients encompasses a variety of molecules: 20 amino acids from protein, simple and complex sugars from carbohydrates, and unsaturated and polyunsaturated fatty acids from fat, which could individually influence ovarian function. For example, adding back only essential amino acids rescued the reduced fecundity in Drosophila females fed a restricted diet (Grandison et al. 2009). Moreover, elimination of a single amino acid, methionine, from a full diet resulted in females laying fewer eggs while adding back methionine alone showed the same rescue of egg production as adding back essential amino acids (Grandison et al. 2009). Recently, it was shown that the effect of dietary methionine on egg production is concentration dependent and influenced by the presence of other amino acids (Lee et al. 2014). Arginine has also been shown to influence Drosophila ovarian function. Increasing or decreasing the concentration of arginine alone in the fly diet resulted in increased or decreased egg laying, respectively (Piper et al. 2017). While carbohydrates do not support Drosophila ovarian function as robustly as protein, specific carbohydrates differentially affect egg production when provided in a diet containing a constant amount of protein. Female flies fed the monosaccharides glucose or fructose, individually or in combination, lay significantly more eggs than their counterparts fed the disaccharide sucrose (Lushchak et al. 2014). Taken together, these studies highlight the specificity of individual macronutrients in controlling ovarian function. 


\section{Nutrition controls Drosophila egg production at multiple points during oogenesis}

The cellular responses that occur during oocyte development in response to a protein-poor diet have been well characterized for Drosophila females. In ovaries of adult female flies fed a protein-poor diet, germline and follicle stem cells show reduced proliferation rates (Drummond-Barbosa \& Spradling 2001) and GSCs are lost more rapidly from the stem cell niche (Hsu \& Drummond-Barbosa 2009). Germline cysts present in the germarium exhibit an increase in programmed cell death as well as autophagy in females fed a protein-poor diet (Drummond-Barbosa \& Spradling 2001, Hou et al. 2008, Barth et al. 2011). Increased cell death rates during mid-oogenesis, egg chambers stages 7-9, are also observed under protein-poor dietary conditions (Drummond-Barbosa \& Spradling 2001, Pritchett et al. 2009). Upon exit from the germarium, discrete egg chambers are developmentally delayed due to reduced proliferation of somatic follicle cells and defects in the mitotic-to-endocycle switch of nurse cells (Drummond-Barbosa \& Spradling 2001, Jouandin et al. 2014). Protein-poor dietary conditions also induce microtubule reorganization, leading to perturbed nurse cell transport to the developing oocyte (Shimada et al. 2011). Moreover, protein-deficient diets result in ovaries in which vitellogenesis, yolk protein and lipid uptake by the oocyte, is blocked (Drummond-Barbosa \& Spradling 2001, Terashima \& Bownes 2004, Mazzalupo \& Cooley 2006, Pritchett \& McCall 2012). Lastly, mature oocytes are retained within the ovary, failing to be ovulated (Drummond-Barbosa \& Spradling 2001). Not surprisingly, many of these effects of protein-poor diet are reversible, allowing female flies that are re-fed a normal diet to increase egg production (DrummondBarbosa \& Spradling 2001). For example, feeding a protein-rich diet to previously starved female flies reverses the microtubule reorganization induced by protein-poor diet, thus restoring intercellular transport from nurse cells to the oocyte (Shimada et al. 2011). Thus, nutritional input influences multiple stages of oogenesis at the cellular level to ultimately affect the final readout of ovarian function and egg production.

\section{Molecular mechanisms involved in the nutritional control of ovarian function in Drosophila}

A complex interplay between diet-dependent hormones, nutrient sensing, and inter-organ communication mediate the effects of diet on ovarian function. Drosophila melanogaster's extensive genetic toolkit in combination with reliable cell biological methods has allowed investigators to uncover the mechanism of action of several highly conserved signaling pathways, including insulin/insulin-like growth factor signaling (IIS), steroid hormone signaling, as well as target of rapamycin (TOR) and AMP-activated protein kinase (AMPK)-mediated signaling. For more detailed discussion on the material described below, readers are directed to several excellent reviews on Drosophila ovarian response to diet (Ables et al. 2012, Ables \& Drummond-Barbosa 2017, Laws \& Drummond-Barbosa 2017, Templeman \& Murphy 2018, Mirth et al. 2019).

In Drosophila, insulin-like peptide (ILP) binding to a single insulin receptor (InR) activates two main downstream signaling cascades, the PI3K/Akt and Ras/MAPK axes (Boucher et al. 2014). Of the seven ILPs, ILPs 2,3, and 5 are secreted from brain median neurosecretory cells in response to feeding to control oocyte development (Ikeya et al. 2002, LaFever \& Drummond-Barbosa 2005). These brain-derived ILPs act directly on the ovarian germline, promoting GSC proliferation, egg chamber growth and progression through vitellogenesis (LaFever \& DrummondBarbosa 2005). They also act on GSC niche cap cells to indirectly maintain GSCs by regulating niche size, that is, cap cell number, and cadherin-dependent adhesion of GSCs to cap cells (Hsu \& Drummond-Barbosa 2009, Hsu \& Drummond-Barbosa 2011, Yang et al. 2013). Follicle cells also employ IIS to mediate starvation-induced microtubule reorganization and P-body aggregation in underlying previtellogenic egg chambers that serves as a protective mechanism against nutrient stress (Burn et al. 2015). Moreover, cell-autonomous IIS controls the mitoticto-endocycle cell switch in follicle cells, which correlates with vitellogenic entry of mid-stage egg chambers (Jouandin et al. 2014).

The diet-dependent steroid hormone ecdysone, known for its role in timing transitions during larval development (Yamanaka et al. 2013), functions in the nutrient response of the Drosophila ovary throughout oogenesis. Ecdysone binds to its heterodimeric nuclear hormone ecdysone receptor and ultraspiracle (EcR/ USP) to act on targets like E74, E75 and broad, early response genes expressed in the ovary (Riddiford et al. 2000, Belles \& Piulachs 2015). In the Drosophila ovary, ecdysone signaling functions cell-autonomously to promote GSC maintenance and proliferation (Ables \& Drummond-Barbosa 2010) and non-cell-autonomously in escort cells to regulate germline differentiation, including the formation of multicellular cysts, oocyte meiotic entry and egg chamber formation (König et al. 2011, Morris \& Spradling 2012). Furthermore, survival of previtellogenic and vitellogenic egg chambers requires ecdysone signaling (Buszczak et al. 1999, Carney \& Bender 2000, Ables et al. 2015). Recently, a host of ecdysone-responsive genes have been identified that function in the control of GSC and FSC maintenance, germline cyst and ovarian somatic cell development, as well as encapsulation (Ables et al. 2016). An intricate crosstalk mechanism exists between IIS and ecdysone signaling whereby each diet-dependent pathway influences activity of the other and modulate similar aspects of oogenesis. 
In addition to controlling growth in a variety of cell and tissue types across organisms, the amino acid sensor, TOR, and glucose and energy sensor, AMPK, function in Drosophila to control ovarian response to nutritional status (Grewal 2009, Bland et al. 2010, Ben-Sahra \& Manning 2017, Lin \& Hardie 2018). Cell-autonomous TOR-mediated signaling regulates GSC maintenance and proliferation as well as early germline cyst survival (LaFever et al. 2010, Sun et al. 2010). Egg chamber growth relies on TOR signaling within the germline (LaFever et al. 2010). Moreover, follicle cell size, controlled intrinsically by TOR, indirectly modulates growth of the underlying germline cyst to match growth of somatic and germ cells in the developing egg chamber (LaFever et al. 2010). Similar to IIS, TOR-mediated signaling modulates the mitotic-to-endocycle switch and progression through vitellogenesis (LaFever et al. 2010, Pritchett \& McCall 2012). Interestingly, regulators of TOR activity control oocyte meiotic entry, but seem to do so independent of dietary input (Wei et al. 2014). Like TOR signaling, AMPK has a diet-independent function in follicle cell encapsulation of germline cysts (Laws \& Drummond-Barbosa 2016). Importantly, however, AMPK is responsible for mediating several effects on oogenesis elicited by a protein-poor diet, including the decrease in GSC and follicle cell proliferation (Laws \& Drummond-Barbosa 2016). Similar to the non-cellautonomous role of TOR-mediated follicle cell signaling in controlling germline growth, AMPK functions in follicle cells to restrict germline cyst growth in female flies fed a poor diet (Laws \& Drummond-Barbosa 2016).

Given that multiple organs sense and respond to changes in nutritional input, the role that inter-organ communication plays in coordinating whole organism physiological responses has received increasing attention (Droujinine \& Perrimon 2013).

Specifically, Drosophila adipose tissue, or the fat body, has recently arisen as a nutrient-sensing depot that refines the ovarian response to diet at multiple stages of oogenesis. Adipocytes, the primary cell type of Drosophila adipose tissue, regulate GSCs and their progeny using a variety of nutrient-sensing and metabolic pathways. First, GSCs are maintained by adipocyte sensing of amino acids via the amino acid response pathway (Armstrong et al. 2014) and by the IIS/Akt/GSK3beta axis (Armstrong \& Drummond-Barbosa 2018). Furthermore, adipocyte IIS promotes germline cyst survival via InR/Akt signaling and as yet to be identified Akt targets (Armstrong \& Drummond-Barbosa 2018). Intriguingly, progression through vitellogenesis is also influenced by adipocyte InR activity, but not through the canonical PI3K/Akt axis (Armstrong \& Drummond-Barbosa 2018). Lastly, TOR-dependent amino acid sensing in adult adipocytes promotes ovulation of mature oocytes (Armstrong et al. 2014). In Drosophila adipose tissue, metabolic enzymes and nutrient transport proteins expressed in a dietdependent manner have been shown to control ovarian function. For example, several enzymes involved in fatty acid oxidation are down regulated in fat bodies from females fed a protein-poor diet and are important for GSC maintenance under fed conditions (Matsuoka et al. 2017).

Taken together, findings from the described studies underscore the multifaceted regulation of Drosophila ovarian function. Not only do different cell types within the ovary use a variety of nutrient-sensing pathways to directly respond to dietary changes, somatic and germ cells within the ovary communicate this information to each other. As an added level of regulation, IIS and TOR-mediated signaling are used again in the adipose tissue to control similar aspects of oogenesis. It remains to be determined if AMPK also functions in adipose tissue to communicate information about nutritional status to the ovary. In multicellular organisms, humans and Drosophila alike, whole organism physiological responses to nutrition depend on interorgan communication (Droujinine \& Perrimon 2013). Therefore, it is important to identify the factors, and their modes of action, which relay nutritional information in a complex network of tissue crosstalk. The ability to manipulate gene expression tissue specifically firmly positions Drosophila melanogaster as an in vivo model system to address this challenge. In fact, several studies in adult flies have shown inter-organ communication from muscle-to-fat, fat-to-brain, and fat-to-ovary (Rajan \& Perrimon 2013, Demontis et al. 2014, studies described in this review). In future studies, it will be interesting to determine if other nutrient-responsive tissues, such as the gut and muscle, also act to refine the ovarian response to diet.

\section{Dietary manipulations for Drosophila melanogaster}

Drosophila melanogaster is incredibly amenable to dietary manipulations, including alterations of food composition and quantity, as well as feeding schedule. While a variety of feeding media exist, nearly all contain ingredients that provide the three main macronutrients, protein, carbohydrates and lipids. For general fly maintenance, Drosophila biologists use a standard, or undefined, medium of yeast, sugar, cornmeal/ corn flour, agar, and water with or without anti-fungal or preservation agents (Table 1). The source of each ingredient varies depending on the fly food recipe being used; for example, Baker's versus Brewer's yeast or corn syrup versus sucrose, for the protein or carbohydrate source, respectively. Despite these slight differences, standard diets are composed of $1.5-10 \%$ yeast, $5-10 \%$ cornmeal, $5-10 \%$ sugar, and $0.5-3 \%$ agar (percentages are $\mathrm{w} / \mathrm{v}$ ). To achieve broad manipulations, like dietary restriction, high-fat or high-sugar diets, standard medium can be modified by removing or adding ingredients. For dietary restriction, the quantity of yeast is usually reduced by half (Bass et al. 2007), while the 
Table 1 Ingredients for example standard, semi-defined, and chemically defined Drosophila diets.

\begin{tabular}{|c|c|c|c|}
\hline & Standard (BDSC) & Meridic (Reis 2016) & Holidic (Piper et al. 2017) \\
\hline Protein & $\begin{array}{l}\text { Baker's yeast (16); Soy } \\
\text { flour (10) }\end{array}$ & Casein (73.3) & $\begin{array}{l}\text { Alanine (1.1); Arginine (1.63); Asparagine (1.03); Aspartate (1.17); } \\
\text { Cysteine (0.34); Glutamate (1.52); Glutamine (1.12); Glycine (0.77); } \\
\text { Histidine (0.65); Isoleucine (1.12); Leucine (2.03); Lysine (1.37); } \\
\text { Methionine (0.6); Phenylalanine (1.01); Proline (0.98); Serine (1.38); } \\
\text { Threonine (1.11); Tryptophan (0.32); Tyrosine (0.93); Valine (1.2) }\end{array}$ \\
\hline Carbohydrates & Light corn syrup (7\% v/v) & Sucrose (13.3) & Sucrose (17.12) \\
\hline Lipids & Yellow cornmeal (67) & Cholesterol $(0.4)$ & Cholesterol $(0.1)$ \\
\hline Other & Agar (5) & $\begin{array}{l}\text { Agar (5); Choline }(0.32) \\
\text { Inosine }(0.85) ; \text { Uridine } \\
(0.76)\end{array}$ & $\begin{array}{l}\text { Agar (20); Inositol (0.005); Choline (0.05); Inosine (0.65); Uridine (0.06); } \\
\text { Thiamine/B1 (0.0014); Riboflavin/B2 (0.0007); Nicotinate/B3 (0.0084); } \\
\text { Pantothenate/B5 (0.0108); Pyridoxine/B6 (0.0017); Biotin/B7 (0.0001); } \\
\text { Folic acid/B9 (0.0005) }\end{array}$ \\
\hline
\end{tabular}

Concentrations in $\mathrm{g} / \mathrm{L}$ for all except where indicated.

amount of sugar added is $2-3 \mathrm{X}$ more for a high-sugar diet (Musselman et al. 2011) and coconut oil is added for a high-fat diet (Birse et al. 2010). Importantly, flies and mammals fed these diets share many phenotypes regarding lifespan, reproduction and metabolism (Trinh \& Boulianne 2013).

In efforts to standardize diets for studies that aim to better understand the nutritional control of Drosophila physiology, several semi-defined (meridic) and chemically defined (holidic) diets have been developed (Table 1; Piper 2017). Unlike standard diets, meridic and holidic media use defined macronutrient sources. While live yeast serves as the protein source in standard diets, meridic diets contain casein and holidic diets use explicit concentrations of individual amino acids (reviewed in Piper 2017). In addition, meridic and holidic diets can contain single or specific combinations of glucose, fructose, sucrose, lactose, and trehalose as the carbohydrate source and lecithin, cholesterol, ergosterol, or inositol as the lipid source (Table 1, Piper 2017). Additional ingredients not added to standard diets include nucleosides, trace metals, and vitamins. As a testament to the inextricable link between nutritional input and organismal physiology, complete diets that only differ in their macronutrient source and concentration exert their own influence on developmental timing, egg production and survival. For example, female flies fed a meridic diet containing sucrose and casein at a high P:C survive longer than female flies fed a holidic diet containing glucose, sucrose, lactose, trehalose and purified amino acids at a low P:C (Lee \& Micchelli 2013, Reis 2016). Thus, 'control' diets should elicit a response from which deviations in either direction for a given physiological response are readily apparent. Regarding egg production, female flies fed a sucrose-based diet supplemented with wet yeast paste (i.e. protein-rich) lay an average of 90 eggs/day while those fed only sucrose (i.e. protein-poor) lay an average of 1.5 eggs/day (Drummond-Barbosa \& Spradling 2001). Therefore, a meridic diet like that used by Sang and King (1961) or a holidic diet like that used by Lee and Micchelli (2013) which result in females that lay approximately 50 eggs per day provide a baseline to which dietary manipulations can be compared. The dramatic response of the Drosophila ovary to dietary changes underscores the need to pay special attention to nutrient composition for studies in which ovarian function is being assessed.

\section{Tools to analyze the Drosophila ovary}

The overall cellular organization and stages required for proper oocyte development (Spradling 1993) have been well described owing to the extensive Drosophila melanogaster toolkit. Established cell biological methods in combination with genetic techniques allow visualization and quantification of ovarian cellular composition (stem cells, germline, somatic cells, cyst types, etc.). A core set of antibodies and transgenic reporter lines are routinely used to mark ovarian cell types (Lie-Jensen \& Haglund 2016). Antibodies that recognize VASA, a DEAD-box RNA helicase required for oogenesis in Drosophila (reviewed in Lasko 2013) label germ cell cytoplasm (Lasko \& Ashburner 1990) (Fig. 2A, C and F), while an anti-orb antibody is enriched in the oocyte (Lantz et al. 1994). Labeling ovaries with antibodies that target alpha-spectrin, phosphorylatedMAPK (pMAPK) or fasciclin III identifies somatic cell populations like escort cells and follicle cells (Fig. 2D and $\mathrm{H})$. A transgenic fly line in which the gene encoding Fax, a membrane protein involved in axon formation, has an in-frame GFP can be used to highlight all somatic cells (Buszczak et al. 2007). For analyses focused on stem cell niche and germline stem cells, antibodies against LaminC (labels terminal filament and cap cell nuclear lamina) and phosphorylated-Mad as well as Nanos (labels germline stem cells) are generally used (Lie-Jensen \& Haglund 2016). Transgenic lines in which genes important for maintenance of stemness are fused to reporter genes, like dad-lacZ and bam::GFP, are often used to highlight germline stem cells (Song et al. 2004). Antibodies that recognize $\mathrm{Hts}-\mathrm{F}$ and alpha-spectrin label the fusome, a specialized structure in germline cysts whose branching morphology correlates with cyst cell number/stage in the germarium (de Cuevas \& Spradling 1998) (Fig. 2E, F and G). 

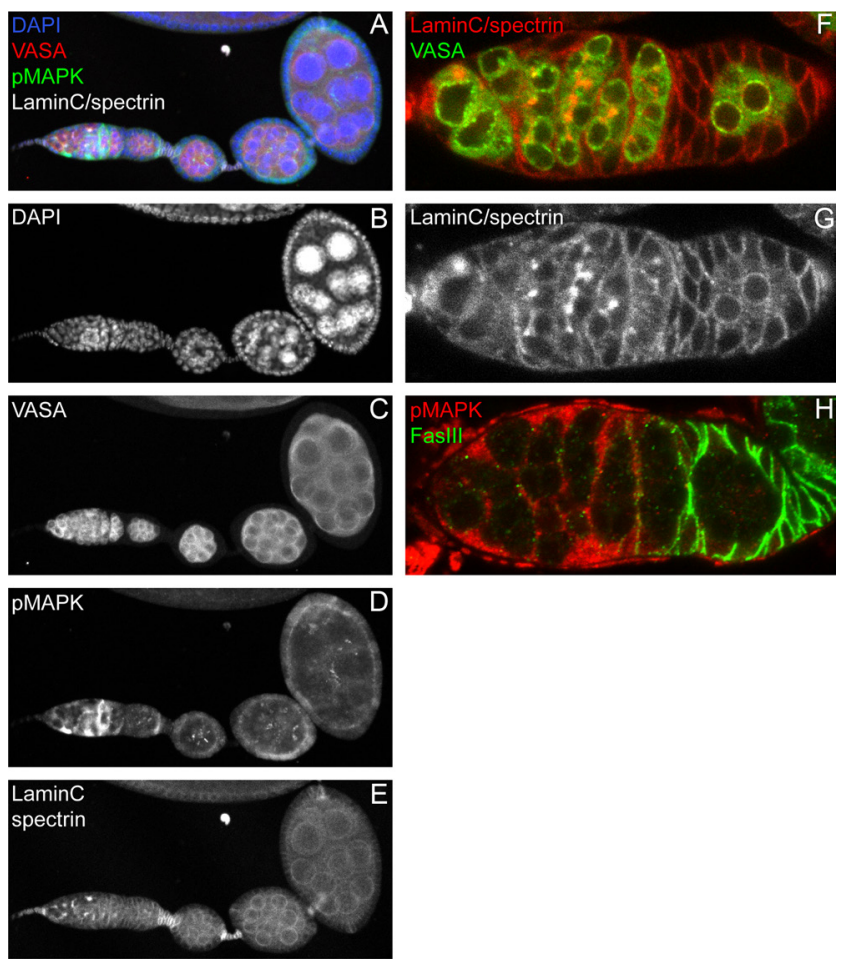

Figure 2 Commonly used antibodies in the Drosophila ovary. (A, B, C, D and E) 20× magnification confocal images of whole ovarioles labeled with DAPI to visualize nuclei (blue in A and B), VASA to visualize germ cells (red in A and C), pMAPK to visualize somatic cells (green in A and D), LaminC and alpha-spectrin to label cap cell nuclei, fusomes and cell membranes (grayscale in $A$ and $E$ ). ( $F, G$ and H) $63 \times$ magnification images of germaria. (F) Germ cells (green), fusomes and cell membranes (red). (G) Single channel, grayscale image of LaminC and alpha-spectrin. (H) Escort cells (red) and follicle cells (FasllI, green).

While preparation of ovarian tissue for immunocytochemical analysis varies depending on the structures to be visualized, most protocols include a fixation step, followed by washing in PBS with or without detergent, a blocking step, incubation in primary antibodies followed by incubation in the appropriate fluorescently tagged secondary antibodies (Lie-Jensen \& Haglund 2016). Protocols can vary at each step including (1) fixative type (aldehyde- vs alcohol-based), time and temperature, (2) detergent type (Triton-X-100 vs Tween20) and concentration, and (3) antibody incubation time and temperature. Therefore, immunocytochemical protocol optimization should be a first step when using new/unfamiliar antibodies.

Like the mammalian ovary, oocyte formation in Drosophila requires proper regulation of cellular proliferation, survival, and changes in gene expression. A variety of antibodies and reagents are used to evaluate these fundamental cellular processes. Proliferation of germline stem cells, germline cyst cells and follicle cells supports robust egg production in well-fed Drosophila females and division of these cell types is decreased under nutrient-poor conditions (DrummondBarbosa \& Spradling 2001, Ables et al. 2012). Using a combination of cell labeling (described above) and Click iT chemistry, proliferation rate in the Drosophila ovary is often measured by quantifying the percentage of cells that incorporate 5-ethynl-2'-deoxyuridine (EdU), a thymidine analog. In addition, a snapshot of cell division can be obtained by phospho-histone $\mathrm{H} 3$ (PH3) antibody labeling that identifies cells undergoing mitotic divisions. Apoptotic and autophagic forms of programmed cell death function in the Drosophila ovary to support normal oocyte formation or respond to environmental stressors (Jenkins et al. 2013, Peterson et al. 2015). For example, nutrient-poor conditions lead to increased apoptosis and autophagy in the germline as well as somatic cells in early and middle stages of oogenesis (Drummond-Barbosa \& Spradling 2001, Hou et al. 2008, Nezis et al. 2009, Barth et al. 2011). To assess apoptotic cell death in the Drosophila ovary, immunoreactivity to an effector caspase, cleaved Dcp1, and/or TUNEL labeling are often used (Meehan et al. 2015) along with the presence of pyknotic nuclei highlighted by DAPI staining. To assess autophagic cell death, a dye that labels acidic organelles (LysoTracker) is used as a proxy for the presence of autophagosomes (DeVorkin \& Gorski 2014) in addition to transgenic fly lines in which proteins required for autophagy are fluorescently tagged (mCherry-Atg8 and LC3-GFP) (Hou et al. 2008, Nezis et al. 2009). Changes in gene expression drive the highly coordinated processes required for proper development of mature oocytes (Spradling 1993, Baker \& Russell 2009, Adrian \& Comeron 2013). As described, dietary manipulations often negatively influence formation of mature oocytes. GFP protein-trap lines, in which proteins are tagged with green fluorescent protein at endogenous loci (Morin et al. 2001, Kelso et al. 2004, Buszczak et al. 2007), have been used to visualize factors expressed in the ovary that are modulated by diet (Hsu \& DrummondBarbosa 2017).

\section{Manipulation of gene expression in the Drosophila ovary}

The exquisite ability to alter gene expression is a major strength of using Drosophila melanogaster as a model system. The FLP/FRT system uses flippase $(F L P)$ mediated recombination of genomic elements flanked by FLP recognition target $(F R T)$ sites to generate clones of mutant cells juxtaposed to cells with wild-type gene function (Xu \& Rubin 1993). Genetic mosaic analysis in the Drosophila ovary using fly lines carrying mutant alleles for nutrient-sensing pathway components (Table 2) (Laws et al. 2015) has uncovered roles for IIS, ecdysone, TOR- and AMPK-mediated signaling in GSCs, 
Table 2 Fly lines carrying mutant alleles for nutrient-sensing pathway components.

\begin{tabular}{|c|c|c|}
\hline Pathway & Mutant alleles & References \\
\hline IIS & $\begin{array}{l}\text { chico }^{1}, \operatorname{din} r^{E 19}, \operatorname{din} r^{339}, \operatorname{din} r^{353}, \text { dFOXO } \\
\text { dFOXO }\end{array}$ & $\begin{array}{l}\text { Fernandez et al. (1995), Chen et al. (1996), (Böhni et al. 1999), Brogiolo et al. } \\
\text { (2001), Fernandez et al. (1995); (Jünger et al. 2003) }\end{array}$ \\
\hline TOR & $\operatorname{Tor}^{R 248 X}, \operatorname{Tor}^{P 2293 L}, \operatorname{Tor}^{\text {W1251X }}$, TsC1 $^{\mathrm{Q} 87 X}$ & Tapon et al. (2001), Zhang et al. (2006) \\
\hline AMPK & $A M P K \alpha^{D 2}, A M P K \alpha^{1}, A M P K \alpha^{A}$ & Lee et al. (2007), Haack et al. (2013), Haelterman et al. (2014) \\
\hline
\end{tabular}

FSCs, and their progeny in response to dietary changes (Ables et al. 2012, Laws \& Drummond-Barbosa 2017).

The Gal4/Gal80ts/UAS system, a mainstay in Drosophila genetic manipulation, allows tissue/celltype specificity as well as temporal control of gene expression (Brand \& Perrimon 1993, del Valle Rodríguez et al. 2011). In this bipartite genetic tool, one transgenic fly line harbors a tissue-specific promoter that controls the expression of the transcription factor Gal4, while a second transgenic fly line harbors a transgene of interest downstream of upstream activating sequences (UAS), binding sites for Gal4. Following standard genetic crosses, the gene of interest will be expressed in a specific tissue in progeny containing Gal4 and UAS genetic elements. Incorporating a temperature-sensitive inhibitor of Gal4, Gal80 ts, provides temporal control of gene expression as switching flies to the permissive or restrictive temperature for Gal80 ${ }^{\text {ts }}$ represses or inhibits transgene expression, respectively. A variety of transgenic Gal4 fly lines are available that drive gene expression in defined cell populations in the Drosophila ovary (Table 3) (Hudson \& Cooley 2014). With appropriate UAS transgenes, gene expression can be modified in several ways. Incorporation of open reading frames downstream of UAS allows overexpression (Bischof et al. 2013), while incorporation of short inverted repeats complementary to a gene of interest downstream of UAS allows RNA interference-mediated knockdown (Kaya-Çopur \& Schnorrer 2016). In addition to fly stocks available at the Bloomington Drosophila Stock Center (BDSC; flystocks.bio.indiana.edu), the Zurich ORFeome Project (FlyORF; flyorf.ch) contains over 3000 overexpression lines covering approximately 2850 genes. The Vienna Drosophila Resource Center (VRDC; stockcenter.vdrc. at) has created and maintains an RNAi library of over 25,000 fly lines, covering 91\% of the genome (Dietzl et al. 2007). The Transgenic RNAi Project (TRiP; flyrnai. org), whose collection is housed at the Bloomington Drosophila Stock Center, has created over 12,000 fly lines and additional tools for the fly community to generate their own RNAi lines ( $\mathrm{Ni}$ et al. 2011). Many transgenic lines exist that allow inhibition or activation of IIS-, TOR-, or AMPK-mediated signaling by targeting various components of each pathway (Table 4). More recently, the CRISPR-Cas9 system has been adapted in Drosophila, including tissue specificity, and will likely play a major role in assessing gene function as the tools are refined (Bassett \& Liu 2014, Port et al. 2019).

\section{Concluding remarks}

Under optimal nutritional conditions, Drosophila melanogaster females are supremely poised for producing a large number of eggs over a significant portion of their lifespan. Many observations over several decades have shown that a wide range of dietary changes manipulating macronutrient levels impinges on ovarian output. Because of the incredible experimental tools available in Drosophila, a host of studies have deciphered numerous cellular and molecular mechanisms that mediate the ovarian response to diet. Importantly, what we have learned from Drosophila is broadly applicable to other organisms, including mammals and humans. Despite some morphological and cell biological differences, human and Drosophila ovaries must both regulate cellular proliferation, survival and differentiation to produce a functional gamete. Likely a result of the multifactorial nature of human

Table 3 Transgenic Gal4 lines driving expression in the Drosophila ovary.

\begin{tabular}{|c|c|c|c|c|c|}
\hline & \multirow[b]{2}{*}{ Gal4 driver name } & \multirow[b]{2}{*}{ Ovarian expression } & \multicolumn{2}{|c|}{ Available Stocks } & \multirow[b]{2}{*}{ References } \\
\hline & & & BDSC & Kyoto & \\
\hline \multirow[t]{6}{*}{ Germ cells } & bam-Gal4:VP16 & Germline stem cells and early germ line & 80579 & $\mathrm{n} / \mathrm{a}$ & Chen and McKearin (2003) \\
\hline & GreenEye.nos-Gal4 & Germline stem cells and germ line & 32180,32179 & $\mathrm{n} / \mathrm{a}$ & Holtzman et al. (2010) \\
\hline & MTD-Gal4 & Germline stem cells and germ line & 31777 & $\mathrm{n} / \mathrm{a}$ & Grieder et al. (2000) \\
\hline & nanos-Gal4 & Germ line cells & 4442,32563 & 107748 & Tracey et al. (2000) \\
\hline & nanos-Gal4-VP16 & Germline stem cells and germ line & $\begin{array}{c}4937,7253,7303 \\
64277,77923\end{array}$ & 107955 & VanDoren et al. (1998) \\
\hline & otu-Gal4::VP16 & Germline stem cells and germ line & 58424 & $\mathrm{n} / \mathrm{a}$ & Rorth (1998) \\
\hline \multirow[t]{5}{*}{ Somatic cells } & bab1-Gal4 & Cap and terminal filament cells & 6802,6803 & $\mathrm{n} / \mathrm{a}$ & Cabrera et al. (2002) \\
\hline & C587-Gal4 & Escort cells and germarium follicle cells & 67747 & $\mathrm{n} / \mathrm{a}$ & Song and Xie (2003) \\
\hline & en2.4-Gal4 & Follicle stem and follicle cells & 1973 & 106609 & Harrison et al. (1995) \\
\hline & GR1-Gal4 & Follicle stem and follicle cells & 36287 & $\mathrm{n} / \mathrm{a}$ & Tran and Berg (2003) \\
\hline & tj-Gal4 & Somatic cells & $\mathrm{n} / \mathrm{a}$ & 104055 & Olivieri et al. (2012) \\
\hline
\end{tabular}


Table 4 UAS-controlled transgenes for nutrient-sensing pathway manipulation.

\begin{tabular}{|c|c|c|}
\hline Pathway & Transgene & Reference \\
\hline IIS & 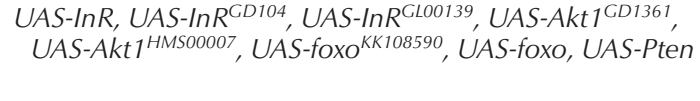 & $\begin{array}{l}\text { Huang et al. (1999), Hwangbo et al. (2004), Tang et al. (2011), Willecke } \\
\text { et al. (2011), Sieber et al. (2016), Armstrong and Drummond-Barbosa } \\
\text { (2018) }\end{array}$ \\
\hline TOR & UAS-TSC1/2, UAS-RagA T16N & Tapon et al. (2001), Kim et al. (2008), Armstrong et al. (2014) \\
\hline AMPK & UAS-AMPK $\alpha^{W T}, U A S-A M P K^{D N}, A M P K^{K K 102684}$ & $\begin{array}{l}\text { Johnson et al. (2010), Stenesen et al. (2013), Laws and } \\
\text { Drummond-Barbosa (2016) }\end{array}$ \\
\hline
\end{tabular}

diet, that is, regional differences, socioeconomic status, psychological and behavioral control, little is known about the underlying biology that links mammalian ovarian function to nutritional status, particularly obesity/ overnutrition. Given the high degree of conservation between organ systems, physiology, nutrient-sensing pathways, and metabolism, Drosophila has developed in to a model for obesity and obesity-related diseases, including metabolic syndrome and type 2 diabetes (Baker \& Thummel 2007, Trinh \& Boulianne 2013, Smith et al. 2014, Álvarez-Rendón, Salceda \& RiesgoEscovar 2018).

\section{Declaration of interest}

The authors declare that there is no conflict of interest that could be perceived as prejudicing the impartiality of this review.

\section{Funding}

This review did not receive any specific grant from any funding agency in the public, commercial or not-for-profit sector.

\section{References}

Ables ET \& Drummond-Barbosa D 2010 The steroid hormone ecdysone functions with intrinsic chromatin remodeling factors to control female germline stem cells in Drosophila. Cell Stem Cell 7 581-592. (https://doi. org/10.1016/j.stem.2010.10.001)

Ables ET \& Drummond-Barbosa D 2017 Steroid hormones and the physiological regulation of tissue-resident stem cells: lessons from the Drosophila Ovary. Current Stem Cell Reports 3 9-18. (https://doi. org/10.1007/s40778-017-0070-z)

Ables ET, Laws KM \& Drummond-Barbosa D 2012 Control of adult stem cells in vivo by a dynamic physiological environment: diet-dependent systemic factors in Drosophila and beyond. Wiley Interdisciplinary Reviews: Developmental Biology 1 657-674. (https://doi.org/10.1002/ wdev.48)

Ables ET, Bois KE, Garcia CA \& Drummond-Barbosa D 2015 Ecdysone response gene E78 controls ovarian germline stem cell niche formation and follicle survival in Drosophila. Developmental Biology 400 33-42. (https://doi.org/10.1016/j.ydbio.2015.01.013)

Ables ET, Hwang GH, Finger DS, Hinnant TD \& Drummond-Barbosa D 2016 A genetic mosaic screen reveals ecdysone-responsive genes regulating Drosophila oogenesis. G3 6 2629-2642. (https://doi. org/10.1534/g3.116.028951)

Adrian AB \& Comeron JM 2013 The Drosophila early ovarian transcriptome provides insight to the molecular causes of recombination rate variation across genomes. BMC Genomics 14 794. (https://doi.org/10.1186/14712164-14-794)

Álvarez-Rendón JP, Salceda R \& Riesgo-Escovar JR 2018 Drosophila melanogaster as a model for diabetes Type 2 progression. BioMed Research International 2018 1417528. (https://doi.org/10.1155/2018/1417528)
Archer CR, Royle N, South S, Selman C \& Hunt J 2009 Nutritional geometry provides food for thought. Journals of Gerontology: Series A, Biological Sciences and Medical Sciences 64 956-959. (https://doi.org/10.1093/ gerona/glp069)

Armstrong AR \& Drummond-Barbosa D 2018 Insulin signaling acts in adult adipocytes via GSK-3 $\beta$ and independently of FOXO to control Drosophila female germline stem cell numbers. Developmental Biology 440 31-39. (https://doi.org/10.1016/j.ydbio.2018.04.028)

Armstrong AR, Laws KM \& Drummond-Barbosa D 2014 Adipocyte amino acid sensing controls adult germline stem cell number via the amino acid response pathway and independently of Target of rapamycin signaling in Drosophila. Development 141 4479-4488. (https://doi.org/10.1242/ dev.116467)

Baker DA \& Russell S 2009 Gene expression during Drosophila melanogaster egg development before and after reproductive diapause. BMC Genomics 10 242. (https://doi.org/10.1186/1471-2164-10-242)

Baker KD \& Thummel CS 2007 Diabetic larvae and obese flies-emerging studies of metabolism in Drosophila. Cell Metabolism 6 257-266. (https://doi.org/10.1016/j.cmet.2007.09.002)

Barth JMI, Szabad J, Hafen E \& Köhler K 2011 Autophagy in Drosophila ovaries is induced by starvation and is required for oogenesis. Cell Death and Differentiation 18 915-924. (https://doi.org/10.1038/cdd.2010.157)

Bass TM, Grandison RC, Wong R, Martinez P, Partridge L \& Piper MDW 2007 Optimization of dietary restriction protocols in Drosophila. Journals of Gerontology: Series A, Biological Sciences and Medical Sciences 62 1071-1081. (https://doi.org/10.1093/gerona/62.10.1071)

Bassett AR \& Liu JL 2014 CRISPR/Cas9 and genome editing in Drosophila. Journal of Genetics and Genomics 41 7-19. (https://doi.org/10.1016/j. jgg.2013.12.004)

Belles X \& Piulachs MD 2015 Ecdysone signalling and ovarian development in insects: from stem cells to ovarian follicle formation. Biochimica et Biophysica Acta 1849 181-186. (https://doi.org/10.1016/j. bbagrm.2014.05.025)

Ben-Sahra I \& Manning BD 2017 mTORC1 signaling and the metabolic control of cell growth. Current Opinion in Cell Biology 45 72-82. (https://doi.org/10.1016/j.ceb.2017.02.012)

Birse RT, Choi J, Reardon K, Rodriguez J, Graham S, Diop S, Ocorr K, Bodmer R \& Oldham S 2010 High-fat-diet-induced obesity and heart dysfunction are regulated by the TOR pathway in Drosophila. Cell Metabolism 12 533-544. (https://doi.org/10.1016/j.cmet.2010.09.014)

Bischof J, Björklund M, Furger E, Schertel C, Taipale J \& Basler K 2013 A versatile platform for creating a comprehensive UAS-ORFeome library in Drosophila. Development 140 2434-2442. (https://doi.org/10.1242/ dev.088757)

Bland ML, Lee RJ, Magallanes JM, Foskett JK \& Birnbaum MJ 2010 AMPK supports growth in Drosophila by regulating muscle activity and nutrient uptake in the gut. Developmental Biology 344 293-303. (https://doi. org/10.1016/j.ydbio.2010.05.010)

Böhni R, Riesgo-Escovar J, Oldham S, Brogiolo W, Stocker H, Andruss BF, Beckingham K \& Hafen E 1999 Autonomous control of cell and organ size by CHICO, a Drosophila homolog of vertebrate IRS1-4. Cell 97 865-875. (https://doi.org/10.1016/s0092-8674(00)80799-0)

Boucher J, Kleinridders A \& Kahn CR 2014 Insulin receptor signaling in normal and insulin-resistant states. Cold Spring Harbor Perspectives in Biology 6 1-23. (https://doi.org/10.1101/cshperspect.a009191)

Bownes M \& Blair M 1986 The effects of a sugar diet and hormones on the expression of the Drosophila yolk-protein genes. Journal of Insect Physiology 32 493-501. (https://doi.org/10.1016/00221910(86)90011-9)

Bradley TJ \& Simmons FH 1997 An analysis of resource allocation in response to dietary yeast in Drosophila melanogaster. Journal 
of Insect Physiology 43 779-788. (https://doi.org/10.1016/S00221910(97)00037-1)

Brand AH \& Perrimon N 1993 Targeted gene expression as a means of altering cell fates and generating dominant phenotypes. Development 118 401-415.

Brogiolo W, Stocker H, Ikeya T, Rintelen F, Fernandez R \& Hafen E 2001 An evolutionarily conserved function of the Drosophila insulin receptor and insulin-like peptides in growth control. Current Biology 11 213-221. (https://doi.org/10.1016/s0960-9822(01)00068-9)

Brookheart RT \& Duncan JG 2016 Modeling dietary influences on offspring metabolic programming in Drosophila melanogaster. Reproduction 152 R79-R90. (https://doi.org/10.1530/REP-15-0595)

Brookheart RT, Swearingen AR, Collins CA, Cline LM \& Duncan JG 2017 High-sucrose-induced maternal obesity disrupts ovarian function and decreases fertility in Drosophila melanogaster. Biochimica et Biophysica Acta 1863 1255-1263. (https://doi.org/10.1016/j.bbadis.2017.03.014)

Bross TG, Rogina B \& Helfand SL 2005 Behavioral, physical, and demographic changes in Drosophila populations through dietary restriction. Aging Cell 4 309-317. (https://doi.org/10.1111/j.14749726.2005.00181.x)

Burn KM, Shimada Y, Ayers K, Vemuganti S, Lu F, Hudson AM \& Cooley L 2015 Somatic insulin signaling regulates a germline starvation response in Drosophila egg chambers. Developmental Biology 398 206-217. (https://doi.org/10.1016/j.ydbio.2014.11.021)

Buszczak M, Freeman MR, Carlson JR, Bender M, Cooley L \& Segraves WA 1999 Ecdysone response genes govern egg chamber development during mid-oogenesis in Drosophila. Development 126 4581-4589.

Buszczak M, Lu X, Segraves WA, Chang TY \& Cooley L 2002 Mutations in the midway gene disrupt a Drosophila acyl coenzyme A: diacylglycerol acyltransferase. Genetics 160 1511-1518.

Buszczak M, Paterno S, Lighthouse D, Bachman J, Planck J, Owen S, Skora AD, Nystul TG, Ohlstein B, Allen A et al. 2007 The carnegie protein trap library: a versatile tool for Drosophila developmental studies. Genetics 175 1505-1531. (https://doi.org/10.1534/ genetics.106.065961)

Cabrera GR, Godt D, Fang PY, Couderc JL \& Laski FA 2002 Expression pattern of Gal4 enhancer trap insertions into the bric à brac locus generated by $\mathrm{P}$ element replacement. Genesis 34 62-65. (https://doi. org/10.1002/gene.10115)

Carney GE \& Bender M 2000 The Drosophila ecdysone receptor (EcR) gene is required maternally for normal oogenesis. Cenetics 154 1203-1211.

Chapman T \& Partridge L 1996 Female fitness in Drosophila melanogaster: an interaction between the effect of nutrition and of encounter rate with males. Proceedings of the Royal Society of London. Series B: Biological Sciences 263 755-759. (https://doi.org/10.1098/rspb.1996.0113)

Chen D \& McKearin DM 2003 A discrete transcriptional silencer in the bam gene determines asymmetric division of the Drosophila germline stem cell. Development 130 1159-1170. (https://doi.org/10.1242/dev.00325)

Chen C, Jack J \& Garofalo RS 1996 The Drosophila insulin receptor is required for normal growth. Endocrinology 137 846-856. (https://doi. org/10.1210/endo.137.3.8603594)

Chippindale AK, Leroi AM, Kim SB \& Rose MR 1993 Phenotypic plasticity and selection in Drosophila life-history evolution. I. Nutrition and the cost of reproduction. Journal of Evolutionary Biology 6 171-193. (https:// doi.org/10.1046/j.1420-9101.1993.6020171.x)

Clark A, Meignin C \& Davis I 2007 A Dynein-dependent shortcut rapidly delivers axis determination transcripts into the Drosophila oocyte. Development 134 1955-1965. (https://doi.org/10.1242/dev.02832)

Cordier AG, Léveillé P, Dupont C, Tarrade A, Picone O, Larcher T, Dahirel M, Poumerol E, Mandon-Pepin B, Lévy R et al. 2013 Dietary lipid and cholesterol induce ovarian dysfunction and abnormal LH response to stimulation in rabbits. PLOS ONE 8 e63101. (https://doi. org/10.1371/journal.pone.0063101)

Cox RT \& Spradling AC 2003 A Balbiani body and the fusome mediate mitochondrial inheritance during Drosophila oogenesis. Development 130 1579-1590. (https://doi.org/10.1242/dev.00365)

de Cuevas M \& Spradling AC 1998 Morphogenesis of the Drosophila fusome and its implications for oocyte specification. Development 125 2781-2789.

De Felici M \& Barrios F 2013 Seeking the origin of female germline stem cells in the mammalian ovary. Reproduction 146 R125-R130. (https:// doi.org/10.1530/REP-13-0069)
Delcore L \& Lacoursiere DY 2016 Preconception care of the obese woman. Clinical Obstetrics and Gynecology 59 129-139. (https://doi. org/10.1097/GRF.0000000000000182)

Demontis F, Patel VK, Swindell WR \& Perrimon N 2014 Intertissue control of the nucleolus via a myokine-dependent longevity pathway. Cell Reports 7 1481-1494. (https://doi.org/10.1016/j.celrep.2014.05.001)

DeVorkin L \& Gorski SM 2014 LysoTracker staining to aid in monitoring autophagy in Drosophila. Cold Spring Harbor Protocols 2014 951-958. (https://doi.org/10.1101/pdb.prot080325)

Dietzl G, Chen D, Schnorrer F, Su KC, Barinova Y, Fellner M, Gasser B, Kinsey K, Oppel S, Scheiblauer S et al. 2007 A genome-wide transgenic RNAi library for conditional gene inactivation in Drosophila. Nature $\mathbf{4 4 8}$ 151-156. (https://doi.org/10.1038/nature05954)

Droujinine IA \& Perrimon N 2013 Defining the interorgan communication network: systemic coordination of organismal cellular processes under homeostasis and localized stress. Frontiers in cellular and infection microbiology 82 1-5. (https://doi.org/10.3389/fcimb.2013.00082)

Drummond-Barbosa D \& Spradling AC 2001 Stem cells and their progeny respond to nutritional changes during Drosophila oogenesis. Developmental Biology $231265-278 . \quad$ (https://doi.org/10.1006/ dbio.2000.0135)

El-Hayek S \& Clarke HJ 2016 Control of oocyte growth and development by intercellular communication within the follicular niche. Results and Problems in Cell Differentiation 58 191-224. (https://doi. org/10.1007/978-3-319-31973-5_8)

Fernandez R, Tabarini D, Azpiazu N, Frasch M \& Schlessinger J 1995 The Drosophila insulin receptor homolog: a gene essential for embryonic development encodes two receptor isoforms with different signaling potential. EMBO Journal 14 3373-3384. (https://doi. org/10.1002/j.1460-2075.1995.tb07343.x)

Good TP \& Tatar M 2001 Age-specific mortality and reproduction respond to adult dietary restriction in Drosophila melanogaster. Journal of Insect Physiology 47 1467-1473. (https://doi.org/10.1016/S00221910(01)00138-X)

Gougeon A 2010 Human ovarian follicular development: from activation of resting follicles to preovulatory maturation. Annales D'endocrinologie 71 132-143. (https://doi.org/10.1016/j.ando.2010.02.021)

Grandison RC, Piper MDW \& Partridge L 2009 Amino-acid imbalance explains extension of lifespan by dietary restriction in Drosophila. Nature 462 1061-1064. (https://doi.org/10.1038/nature08619)

Grewal SS 2009 Insulin/TOR signaling in growth and homeostasis: a view from the fly world. International Journal of Biochemistry and Cell Biology 41 1006-1010. (https://doi.org/10.1016/j.biocel.2008.10.010)

Grieder NC, de Cuevas M \& Spradling AC 2000 The fusome organizes the microtubule network during oocyte differentiation in Drosophila. Development 127 4253-4264.

Grieve KM, McLaughlin M, Dunlop CE, Telfer EE \& Anderson RA 2015 The controversial existence and functional potential of oogonial stem cells. Maturitas 82 278-281. (https://doi.org/10.1016/j. maturitas.2015.07.017)

Gu L, Liu H, Gu X, Boots C, Moley KH \& Wang Q 2015 Metabolic control of oocyte development: linking maternal nutrition and reproductive outcomes. Cellular and Molecular Life Sciences 72 251-271. (https://doi. org/10.1007/s00018-014-1739-4)

Haack T, Bergstralh DT \& St Johnston D 2013 Damage to the Drosophila follicle cell epithelium produces 'false clones' with apparent polarity phenotypes. Biology Open 2 1313-1320. (https://doi.org/10.1242/ bio.20134671)

Haelterman NA, Jiang L, Li Y, Bayat V, Sandoval H, Ugur B, Tan KL, Zhang K, Bei D, Xiong B et al. 2014 Large-scale identification of chemically induced mutations in Drosophila melanogaster. Genome Research 24 1707-1718. (https://doi.org/10.1101/gr.174615.114)

Harrison DA, Binari R, Nahreini TS, Gilman M \& Perrimon N 1995 Activation of a Drosophila janus kinase (JAK) causes hematopoietic neoplasia and developmental defects. EMBO Journal 14 2857-2865. (https://doi.org/10.1002/j.1460-2075.1995.tb07285.x)

Heymsfield SB \& Wadden TA 2017 Mechanisms, Pathophysiology, and Management of Obesity. New England Journal of Medicine $\mathbf{3 7 6}$ 254-266. (https://doi.org/10.1056/NEJMra1514009)

Hohos NM \& Skaznik-Wikiel ME 2017 High-fat diet and female fertility. Endocrinology 158 2407-2419. (https://doi.org/10.1210/en.201700371) 
Holtzman S, Miller D, Eisman R, Kuwayama H, Niimi T \& Kaufman T 2010 Transgenic tools for members of the genus Drosophila with sequenced genomes. Fly 4 349-362. (https://doi.org/10.4161/fly.4.4.13304)

Horne-Badovinac S \& Bilder D 2005 Mass transit: epithelial morphogenesis in the Drosophila egg chamber. Developmental Dynamics 232 559-574. (https://doi.org/10.1002/dvdy.20286)

Hou Y-CC, Chittaranjan S, Barbosa SG, McCall K \& Gorski SM 2008 Effector caspase Dcp-1 and IAP protein Bruce regulate starvationinduced autophagy during Drosophila melanogaster oogenesis. Journal of Cell Biology 182 1127-1139. (https://doi.org/10.1083/jcb.200712091)

Hsu HJ \& Drummond-Barbosa D 2009 Insulin levels control female germline stem cell maintenance via the niche in Drosophila. PNAS 106 1117-1121. (https://doi.org/10.1073/pnas.0809144106)

Hsu HJ \& Drummond-Barbosa D 2011 Insulin signals control the competence of the Drosophila female germline stem cell niche to respond to Notch ligands. Developmental Biology 350 290-300. (https:// doi.org/10.1016/j.ydbio.2010.11.032)

Hsu HJ \& Drummond-Barbosa D 2017 A visual screen for diet-regulated proteins in the Drosophila ovary using GFP protein trap lines. Gene Expression Patterns 23-24 13-21. (https://doi.org/10.1016/j.gep.2017.01.001)

Huang H, Potter CJ, Tao W, Li DM, Brogiolo W, Hafen E, Sun H \& Xu T 1999 PTEN affects cell size, cell proliferation and apoptosis during Drosophila eye development. Development 126 5365-5372.

Hudson AM \& Cooley L 2014 Methods for studying oogenesis. Methods 68 207-217. (https://doi.org/10.1016/j.ymeth.2014.01.005)

Hummitzsch K, Anderson RA, Wilhelm D, Wu J, Telfer EE, Russell DL, Robertson SA \& Rodgers RJ 2015 Stem cells, progenitor cells, and lineage decisions in the ovary. Endocrine Reviews 36 65-91. (https://doi. org/10.1210/er.2014-1079)

Hwangbo DS, Gershman B, Tu MP, Palmer M \& Tatar M 2004 Drosophila dFOXO controls lifespan and regulates insulin signalling in brain and fat body. Nature 429 562-566. (https://doi.org/10.1038/nature02549)

Ikami K, Nuzhat N \& Lei L 2017 Organelle transport during mouse oocyte differentiation in germline cysts. Current Opinion in Cell Biology $\mathbf{4 4}$ 14-19. (https://doi.org/10.1016/j.ceb.2016.12.002)

Ikeya T, Galic M, Belawat P, Nairz K \& Hafen E 2002 Nutrient-dependent expression of insulin-like peptides from neuroendocrine cells in the CNS contributes to growth regulation in Drosophila. Current Biology 12 1293-1300. (https://doi.org/10.1016/s0960-9822(02)01043-6)

Jang T \& Lee KP 2018 Comparing the impacts of macronutrients on life-history traits in larval and adult Drosophila melanogaster: the use of nutritional geometry and chemically defined diets. Journal of Experimental Biology 221. (https://doi.org/10.1242/jeb.181115)

Jarrett BY \& Lujan ME 2016 Impact of hypocaloric dietary intervention on ovulation in obese women with PCOS. Reproduction 153 R15-R27. (https://doi.org/10.1530/REP-16-0385)

Jenkins VK, Timmons AK \& McCall K 2013 Diversity of cell death pathways: insight from the fly ovary. Trends in Cell Biology 23 567-574. (https://doi. org/10.1016/j.tcb.2013.07.005)

Jensen K, McClure C, Priest NK \& Hunt J 2015 Sex-specific effects of protein and carbohydrate intake on reproduction but not lifespan in Drosophila melanogaster. Aging Cell 14 605-615. (https://doi. org/10.1111/acel.12333)

Johnson EC, Kazgan N, Bretz CA, Forsberg LJ, Hector CE, Worthen RJ, Onyenwoke R \& Brenman JE 2010 Altered metabolism and persistent starvation behaviors caused by reduced AMPK function in Drosophila. PLoS ONE 5 1-11. (https://doi.org/10.1371/journal.pone.0012799)

Jouandin P, Ghiglione C \& Noselli S 2014 Starvation induces FoxO-dependent mitotic-to-endocycle switch pausing during Drosophila oogenesis. Development 141 3013-3021. (https://doi.org/10.1242/dev.108399)

Jünger MA, Rintelen F, Stocker H, Wasserman JD, Végh M, Radimerski T, Greenberg ME \& Hafen E 2003 The Drosophila forkhead transcription factor FOXO mediates the reduction in cell number associated with reduced insulin signaling. Journal of Biology 2 20. (https://doi. org/10.1186/1475-4924-2-20)

Kaya-Çopur A \& Schnorrer F 2016 A guide to genome-wide in vivo RNAi applications in Drosophila. Methods in Molecular Biology 1478 117-143. (https://doi.org/10.1007/978-1-4939-6371-3_6)

Kelso RJ, Buszczak M, Quiñones AT, Castiblanco C, Mazzalupo S \& Cooley L 2004 Flytrap, a database documenting a GFP protein-trap insertion screen in Drosophila melanogaster. Nucleic Acids Research 32 D418-D420. (https://doi.org/10.1093/nar/gkh014)
Kim E, Goraksha-Hicks P, Li L, Neufeld TP \& Guan KL 2008 Regulation of TORC1 by Rag GTPases in nutrient response. Nature Cell Biology $\mathbf{1 0}$ 935-945. (https://doi.org/10.1038/ncb1753)

König A, Yatsenko AS, Weiss M \& Shcherbata HR 2011 Ecdysteroids affect Drosophila ovarian stem cell niche formation and early germline differentiation. EMBO Journal 30 1549-1562. (https://doi.org/10.1038/ emboj.2011.73)

LaFever L \& Drummond-Barbosa D 2005 Direct control of germline stem cell division and cyst growth by neural insulin in Drosophila. Science 309 1071-1073. (https://doi.org/10.1126/science.1111410)

LaFever L, Feoktistov A, Hsu HJ \& Drummond-Barbosa D 2010 Specific roles of Target of rapamycin in the control of stem cells and their progeny in the Drosophila ovary. Development 137 2117-2126. (https://doi. org/10.1242/dev.050351)

Lantz V, Chang JS, Horabin JI, Bopp D \& SchedI P 1994 The Drosophila orb RNA-binding protein is required for the formation of the egg chamber and establishment of polarity. Genes and Development 8 598-613. (https://doi.org/10.1101/gad.8.5.598)

Lasko P 2013 The DEAD-box helicase vasa: evidence for a multiplicity of functions in RNA processes and developmental biology. Biochimica et Biophysica Acta $\mathbf{1 8 2 9}$ 810-816. (https://doi.org/10.1016/j. bbagrm.2013.04.005)

Lasko PF \& Ashburner M 1990 Posterior localization of vasa protein correlates with, but is not sufficient for, pole cell development. Genes and Development 4 905-921. (https://doi.org/10.1101/gad.4.6.905)

Laws KM \& Drummond-Barbosa D 2016 AMP-activated protein kinase has diet-dependent and -independent roles in Drosophila oogenesis. Developmental Biology $\mathbf{4 2 0}$ 90-99. (https://doi.org/10.1016/j. ydbio.2016.10.006)

Laws KM \& Drummond-Barbosa D 2017 Control of germline stem cell lineages by diet and physiology. Results and Problems in Cell Differentiation 59 67-99. (https://doi.org/10.1007/978-3-319-44820-6_3)

Laws KM, Sampson LL \& Drummond-Barbosa D 2015 Insulin-independent role of adiponectin receptor signaling in Drosophila germline stem cell maintenance. Developmental Biology 399 226-236. (https://doi. org/10.1016/j.ydbio.2014.12.033)

Lee C \& Longo V 2016 Dietary restriction with and without caloric restriction for healthy aging. F1000Research 5 1-7. (https://doi. org/10.12688/f1000research.7136.1)

Lee WC \& Micchelli CA 2013 Development and characterization of a chemically defined food for Drosophila. PLOS ONE 8 e67308. (https:// doi.org/10.1371/journal.pone.0067308)

Lee JH, Koh H, Kim M, Kim Y, Lee SY, Karess RE, Lee SH, Shong M, Kim JM, Kim J et al. 2007 Energy-dependent regulation of cell structure by AMP-activated protein kinase. Nature 447 1017-1020. (https://doi. org/10.1038/nature05828)

Lee KP, Simpson SJ, Clissold FJ, Brooks R, Ballard JWO, Taylor PW, Soran N \& Raubenheimer D 2008 Lifespan and reproduction in Drosophila: new insights from nutritional geometry. PNAS 105 2498-2503. (https://doi. org/10.1073/pnas.0710787105)

Lee BC, Kaya A, Ma S, Kim G, Gerashchenko MV, Yim SH, Hu Z, Harshman LG \& Gladyshev VN 2014 Methionine restriction extends lifespan of Drosophila melanogaster under conditions of low amino-acid status. Nature Communications 5 3592. (https://doi.org/10.1038/ncomms4592)

Lei L \& Spradling AC 2016 Mouse oocytes differentiate through organelle enrichment from sister cyst germ cells. Science 352 95-99. (https://doi. org/10.1126/science.aad2156)

Lie-Jensen A \& Haglund K 2016 Antibody staining in Drosophila Germaria. Methods in Molecular Biology 1457 19-33. (https://doi.org/10.1007/9781-4939-3795-0_3)

Lin SC \& Hardie DG 2018 AMPK: sensing glucose as well as cellular energy status. Cell Metabolism 27 299-313. (https://doi.org/10.1016/j. cmet.2017.10.009)

Lopez AL 3rd, Chen J, Joo HJ, Drake M, Shidate M, Kseib C \& Arur S 2013 DAF-2 and ERK couple nutrient availability to meiotic progression during Caenorhabditis elegans oogenesis. Developmental Cell 27 227-240. (https://doi.org/10.1016/j.devcel.2013.09.008)

Lu K, Jensen L, Lei L \& Yamashita YM 2017 Stay connected: a germ cell strategy. Trends in Genetics 33 971-978. (https://doi.org/10.1016/j. tig.2017.09.001)

Lushchak OV, Gospodaryov DV, Rovenko BM, Glovyak AD, Yurkevych IS, Klyuba VP, Shcherbij MV \& Lushchak VI 2012 Balance between 
macronutrients affects life span and functional senescence in fruit fly Drosophila melanogaster. Journals of Gerontology: Series A, Biological Sciences and Medical Sciences 67 118-125. (https://doi.org/10.1093/ gerona/glr184)

Lushchak OV, Gospodaryov DV, Rovenko BM, Yurkevych IS, Perkhulyn NV \& Lushchak VI 2014 Specific dietary carbohydrates differentially influence the life span and fecundity of Drosophila melanogaster. Journals of Gerontology: Series A, Biological Sciences and Medical Sciences 69 3-12. (https://doi.org/10.1093/gerona/glt077)

Mahowald AP \& Strassheim JM 1970 Intercellular migration of centrioles in the germarium of Drosophila melanogaster. An electron microscopic study. Journal of Cell Biology 45 306-320. (https://doi.org/10.1083/ jcb.45.2.306)

Mair W, Sgrò CM, Johnson AP, Chapman T \& Partridge L 2004 Lifespan extension by dietary restriction in female Drosophila melanogaster is not caused by a reduction in vitellogenesis or ovarian activity. Experimental Gerontology 39 1011-1019. (https://doi.org/10.1016/j. exger.2004.03.018)

Matsuoka S, Armstrong AR, Sampson LL, Laws KM \& DrummondBarbosa D 2017 Adipocyte metabolic pathways regulated by diet control the female germline stem cell lineage in Drosophila melanogaster. Genetics 206 953-971. (https://doi.org/10.1534/genetics.117.201921)

Mazzalupo S \& Cooley L 2006 Illuminating the role of caspases during Drosophila oogenesis. Cell Death and Differentiation 13 1950-1959. (https://doi.org/10.1038/sj.cdd.4401892)

McGrice M \& Porter J 2017 The effect of low carbohydrate diets on fertility hormones and outcomes in overweight and obese women: a systematic review. Nutrients 91-11. (https://doi.org/10.3390/nu9030204)

McLaughlin JM \& Bratu DP 2015 Drosophila melanogaster oogenesis: an overview. Methods in Molecular Biology 1328 1-20. (https://doi. org/10.1007/978-1-4939-2851-4_1)

Meehan TL, Yalonetskaya A, Joudi TF \& McCall K 2015 Detection of cell death and phagocytosis in the drosophila ovary. In Drosophila Oogenesis: Methods and Protocols, pp 191-206. Eds DP Bratu \& GP McNeil. New York, NY: Springer New York.

Meng Y, Bai H, Wang S, Li Z, Wang Q \& Chen L 2017 Efficacy of low carbohydrate diet for type 2 diabetes mellitus management: a systematic review and meta-analysis of randomized controlled trials. Diabetes Research and Clinical Practice 131 124-131. (https://doi.org/10.1016/j. diabres.2017.07.006)

Millburn GH, Crosby MA, Gramates LS, Tweedie S \& FlyBase Consortium 2016 FlyBase portals to human disease research using Drosophila models. Disease Models and Mechanisms 9 245-252. (https://doi. org/10.1242/dmm.023317)

Mirth CK, Nogueira Alves A \& Piper MDW 2019 Turning food into eggs: insights from nutritional biology and developmental physiology of Drosophila. Current Opinion in Insect Science 31 49-57. (https://doi. org/10.1016/j.cois.2018.08.006)

Morin X, Daneman R, Zavortink M \& Chia W 2001 A protein trap strategy to detect GFP-tagged proteins expressed from their endogenous loci in Drosophila. PNAS 98 15050-15055. (https://doi.org/10.1073/ pnas.261408198)

Morris LX \& Spradling AC 2012 Steroid signaling within Drosophila ovarian epithelial cells sex-specifically modulates early germ cell development and meiotic entry. PLOS ONE 7 e46109. (https://doi.org/10.1371/journal. pone.0046109)

Musselman LP, Fink JL, Narzinski K, Ramachandran PV, Hathiramani SS, Cagan RL \& Baranski TJ 2011 A high-sugar diet produces obesity and insulin resistance in wild-type drosophila. Disease Models and Mechanisms 4 842-849. (https://doi.org/10.1242/dmm.007948)

Nezis IP, Lamark T, Velentzas AD, Rusten TE, Bjørkøy G, Johansen T, Papassideri IS, Stravopodis DJ, Margaritis LH, Stenmark H et al. 2009 Cell death during Drosophila melanogaster early oogenesis is mediated through autophagy. Autophagy 5 298-302. (https://doi.org/10.4161/ auto.5.3.7454)

Ni JQ, Zhou R, Czech B, Liu LP, Holderbaum L, Yang-Zhou D, Shim HS, Tao R, Handler D, Karpowicz P et al. 2011 A genome-scale shRNA resource for transgenic RNAi in Drosophila. Nature Methods 8 405-407. (https://doi.org/10.1038/nmeth.1592)

Nicolas E, Chenouard N, Olivo-Marin JC \& Guichet A 2009 A dual role for actin and microtubule cytoskeleton in the transport of Golgi units from the nurse cells to the oocyte across ring canals. Molecular Biology of the Cell 20 556-568. (https://doi.org/10.1091/mbc.e08-04-0360)

Olivieri D, Senti KA, Subramanian S, Sachidanandam R \& Brennecke J 2012 The cochaperone shutdown defines a group of biogenesis factors essential for all piRNA populations in Drosophila. Molecular Cell 47 954-969. (https://doi.org/10.1016/j.molcel.2012.07.021)

Parra-Peralbo E \& Culi J 2011 Drosophila lipophorin receptors mediate the uptake of neutral lipids in oocytes and imaginal disc cells by an endocytosis-independent mechanism. PLoS Genetics 7 e1001297. (https://doi.org/10.1371/journal.pgen.1001297)

Peterson JS, Timmons AK, Mondragon AA \& McCall K 2015 The end of the beginning: cell death in the germline. Current Topics in Developmental Biology 114 93-119. (https://doi.org/10.1016/bs.ctdb.2015.07.025)

Piper MD 2017 Using artificial diets to understand the nutritional physiology of Drosophila melanogaster. Current Opinion in Insect Science 23 104-111. (https://doi.org/10.1016/j.cois.2017.07.014)

Piper MDW, Soultoukis GA, Blanc E, Mesaros A, Herbert SL, Juricic P, He X, Atanassov I, Salmonowicz H, Yang M et al. 2017 Matching dietary amino acid balance to the in silico-translated exome optimizes growth and reproduction without cost to lifespan. Cell Metabolism 25 610-621. (https://doi.org/10.1016/j.cmet.2017.02.005)

Port F, Strein C, Stricker M, Rauscher B, Heigwer F, Zhou J, Beyersdörffer C, Frei J, Hess A, Kern K et al. 2019 A large-scale resource for tissue-specific CRISPR mutagenesis in Drosophila. In bioRxiv, p 636076.

Pritchett TL \& McCall K 2012 Role of the insulin/Tor signaling network in starvation-induced programmed cell death in Drosophila oogenesis. Cell Death and Differentiation 19 1069-1079. (https://doi.org/10.1038/ cdd.2011.200)

Pritchett TL, Tanner EA \& McCall K 2009 Cracking open cell death in the Drosophila ovary. Apoptosis 14 969-979. (https://doi.org/10.1007/ s10495-009-0369-z)

Rajan A \& Perrimon N 2013 Of flies and men: insights on organismal metabolism from fruit flies. BMC Biology 11 38. (https://doi. org/10.1186/1741-7007-11-38)

Reis T 2016 Effects of synthetic diets enriched in specific nutrients on Drosophila development, body fat, and lifespan. PLOS ONE 11 e0146758. (https://doi.org/10.1371/journal.pone.0146758)

Reiter LT, Potocki L, Chien S, Gribskov M \& Bier E 2001 A systematic analysis of human disease-associated gene sequences in Drosophila melanogaster. Genome research $\mathbf{1 1}$ 1114-1125. (https://doi. org/10.1101/gr.169101)

Riddiford LM, Cherbas P \& Truman JW 2000 Ecdysone receptors and their biological actions. In Vitamins and Hormones, pp 1-73. Academic Press. (https://doi.org/10.1016/S0083-6729(00)60016-X)

Rørth P 1998 Gal4 in the Drosophila female germline. Mechanisms of Development 78 113-118. (https://doi.org/10.1016/S09254773(98)00157-9)

Sang JH \& King RC 1961 Nutritional requirements of axenically cultured Drosophila melanogaster adults. Journal of Experimental Biology $\mathbf{3 8}$ 793-809.

Selesniemi K, Lee HJ \& Tilly JL 2008 Moderate caloric restriction initiated in rodents during adulthood sustains function of the female reproductive axis into advanced chronological age. Aging Cell 7 622-629. (https://doi. org/10.1111/j.1474-9726.2008.00409.x)

Shimada Y, Burn KM, Niwa R \& Cooley L 2011 Reversible response of protein localization and microtubule organization to nutrient stress during Drosophila early oogenesis. Developmental Biology 355 250-262. (https://doi.org/10.1016/j.ydbio.2011.04.022)

Sieber MH, Thomsen MB \& Spradling AC 2016 Electron transport chain remodeling by GSK3 during oogenesis connects nutrient state to reproduction. Cell 164 420-432. (https://doi.org/10.1016/j. cell.2015.12.020)

Simpson SJ, Le Couteur DG \& Raubenheimer D 2015 Putting the balance back in diet. Cell 161 18-23. (https://doi.org/10.1016/j.cell.2015.02.033)

Skorupa DA, Dervisefendic A, Zwiener J \& Pletcher SD 2008 Dietary composition specifies consumption, obesity, and lifespan in Drosophila melanogaster. Aging Cell 7 478-490. (https://doi.org/10.1111/j.14749726.2008.00400.x)

Smith WW, Thomas J, Liu J, Li T \& Moran TH 2014 From fat fruit fly to human obesity. Physiology and Behavior 136 15-21. (https://doi. org/10.1016/j.physbeh.2014.01.017) 
Sohrabi M, Roushandeh AM, Alizadeh Z, Vahidinia A, Vahabian M \& Hosseini M 2015 Effect of a high fat diet on ovary morphology, in vitro development, in vitro fertilisation rate and oocyte quality in mice. Singapore Medical Journal 56 573-579. (https://doi.org/10.11622/ smedj.2015085)

Solon-Biet SM, Walters KA, Simanainen UK, McMahon AC, Ruohonen K, Ballard JWO, Raubenheimer D, Handelsman DJ, Le Couteur DG \& Simpson SJ 2015 Macronutrient balance, reproductive function, and lifespan in aging mice. PNAS 112 3481-3486. (https://doi.org/10.1073/ pnas.1422041112)

Song X \& Xie T 2003 Wingless signaling regulates the maintenance of ovarian somatic stem cells in Drosophila. Development $\mathbf{1 3 0}$ 3259-3268. (https://doi.org/10.1242/dev.00524)

Song $\mathrm{X}$, Wong MD, Kawase $\mathrm{E}, \mathrm{Xi}$ R, Ding BC, McCarthy JJ \& Xie T 2004 Bmp signals from niche cells directly repress transcription of a differentiation-promoting gene, bag of marbles, in germline stem cells in the Drosophila ovary. Development 131 1353-1364. (https://doi. org/10.1242/dev.01026)

Spradling AC 1993 Developmental genetics of oogenesis. In The Development of Drosophila melanogaster, pp 1-70. Eds M Bate \& A Martinez Arias. Cold Spring Harbor Laboratory Press.

Spradling A, Fuller MT, Braun RE \& Yoshida S 2011 Germline stem cells. Cold Spring Harbor Perspectives in Biology 3 a002642. (https://doi. org/10.1101/cshperspect.a002642)

Stenesen D, Suh JM, Seo J, Yu K, Lee KS, Kim JS, Min KJ \& Graff JM 2013 Adenosine nucleotide biosynthesis and AMPK regulate adult life span and mediate the longevity benefit of caloric restriction in flies. Cell Metabolism 17 101-112. (https://doi.org/10.1016/j.cmet.2012.12.006)

Sun P, Quan Z, Zhang B, Wu T \& Xi R 2010 TSC1/2 tumour suppressor complex maintains Drosophila germline stem cells by preventing differentiation. Development 137 2461-2469. (https://doi.org/10.1242/dev.051466)

Sundström P, Nilsson BO, Liedholm P \& Larsson E 1985 Ultrastructure of maturing human oocytes. Annals of the New York Academy of Sciences 442 324-331. (https://doi.org/10.1111/j.1749-6632.1985.tb37536.x)

Tang HY, Smith-Caldas MSB, Driscoll MV, Salhadar S \& Shingleton AW 2011 FOXO regulates organ-specific phenotypic plasticity in Drosophila. PLoS Genetics 7 e1002373. (https://doi.org/10.1371/journal.pgen.1002373)

Tapon N, Ito N, Dickson BJ, Treisman JE \& Hariharan IK 2001 The Drosophila tuberous sclerosis complex gene homologs restrict cell growth and cell proliferation. Cell 105 345-355. (https://doi.org/10.1016/ s0092-8674(01)00332-4)

Templeman NM \& Murphy CT 2018 Regulation of reproduction and longevity by nutrient-sensing pathways. Journal of Cell Biology 217 93-106. (https://doi.org/10.1083/jcb.201707168)

Terashima J \& Bownes M 2004 Translating available food into the number of eggs laid by Drosophila melanogaster. Genetics 167 1711-1719. (https://doi.org/10.1534/genetics.103.024323)

Tracey WD Jr, Ning X, Klingler M, Kramer SG \& Gergen JP 2000 Quantitative analysis of gene function in the Drosophila embryo. Genetics 154 273-284.

Tran DH \& Berg CA 2003 bullwinkle and shark regulate dorsal-appendage morphogenesis in Drosophila oogenesis. Development 130 6273-6282. (https://doi.org/10.1242/dev.00854)
Trinh I \& Boulianne GL 2013 Modeling obesity and its associated disorders in Drosophila. Physiology 28 117-124. (https://doi.org/10.1152/ physiol.00025.2012)

del Valle Rodríguez A, Didiano D \& Desplan C 2011 Power tools for gene expression and clonal analysis in Drosophila. Nature Methods 9 47-55. (https://doi.org/10.1038/nmeth.1800)

Van Doren M, Williamson AL \& Lehmann R 1998 Regulation of zygotic gene expression in Drosophila primordial germ cells. Current Biology $\mathbf{8}$ 243-246. (https://doi.org/10.1016/s0960-9822(98)70091-0)

Wang YY, Sun YC, Sun XF, Cheng SF, Li B, Zhang XF, De Felici M \& Shen W 2017 Starvation at birth impairs germ cell cyst breakdown and increases autophagy and apoptosis in mouse oocytes. Cell Death and Disease 8 e2613. (https://doi.org/10.1038/cddis.2017.3)

Wei Y, Reveal B, Reich J, Laursen WJ, Senger S, Akbar T, lida-Jones T, Cai W, Jarnik M \& Lilly MA 2014 TORC1 regulators Iml1/GATOR1 and GATOR2 control meiotic entry and oocyte development in Drosophila. PNAS 111 E5670-E5677. (https://doi.org/10.1073/pnas.1419156112)

Wheeler D 1996 The role of nourishment in oogenesis. Annual Review of Entomology 41 407-431. (https://doi.org/10.1146/annurev. en.41.010196.002203)

Willecke M, Toggweiler J \& Basler K 2011 Loss of PI3K blocks cell-cycle progression in a Drosophila tumor model. Oncogene 30 4067-4074. (https://doi.org/10.1038/onc.2011.125)

Xu T \& Rubin GM 1993 Analysis of genetic mosaics in developing and adult Drosophila tissues. Development 117 1223-1237..

Yamaguchi M \& Yoshida H 2018 Drosophila as a model organism. In Drosophila Models for Human Diseases, pp 1-10. Ed. M Yamaguchi. Singapore: Springer Singapore.

Yamanaka N, Rewitz KF \& O'Connor MB 2013 Ecdysone control of developmental transitions: lessons from Drosophila research. Annual Review of Entomology 58 497-516. (https://doi.org/10.1146/annurevento-120811-153608)

Yang SA, Wang WD, Chen CT, Tseng CY, Chen YN \& Hsu HJ 2013 $\mathrm{FOXO/Fringe} \mathrm{is} \mathrm{necessary} \mathrm{for} \mathrm{maintenance} \mathrm{of} \mathrm{the} \mathrm{germline} \mathrm{stem} \mathrm{cell}$ niche in response to insulin insufficiency. Developmental Biology $\mathbf{3 8 2}$ 124-135. (https://doi.org/10.1016/j.ydbio.2013.07.018)

Zajitschek F, Zajitschek SRK, Friberg U \& Maklakov AA 2013 Interactive effects of sex, social environment, dietary restriction, and methionine on survival and reproduction in fruit flies. Age 35 1193-1204. (https://doi. org/10.1007/s11357-012-9445-3)

Zhang Y, BillingtonCJ Jr, Pan D \& Neufeld TP 2006 Drosophila target of rapamycin kinase functions as a multimer. Genetics 172 355-362. (https://doi.org/10.1534/genetics.105.051979)

Received 20 November 2018

First decision 20 December 2018

Revised manuscript received 22 August 2019

Accepted 5 September 2019 